Зорана Опачић

zorana.opacic@uf.bg.ac.rs

Учитељски факултет

Универзитет у Београду
УДК 821.163.41-93::378

https://doi.org/10.18485/mks_knsjkk_polozaj.2020.ch7

\title{
КЊИЖЕВНОСТ ЗА ДЕЦУ И МЛАДЕ КАО АКАДЕМСКА ДИСЦИПЛИНА ${ }^{1}$
}

Рад је посвећен развоју проучавања књижевности за децу као академској дисциплини. Заслуге за заснивање ове научне дисциплине на факултетима припадају проф. др Слободану Ж. Марковићу који је иницирао увођење новог наставног предмета крајем 50-их година прошлог века, први у овом делу Европе. Истражујемо на који начин се развијао научни приступ овој области а у ком статусу је она данас - у Србији и земљама региона; укључујући и доминантне начине проучавања и концепте постојећих силабуса. Будући да је реч о дисциплини која се у највећој мери изучава унутар студија националне књижевности и у оквиру наставничких студија, у силабусима преовлађују дела националног канона уз репрезентативни избор дела европске и светске књижевности. На крају, после анализе силабуса, указаћемо на потребу већег присуства словенских књижевности у академским силабусима.

Кључне речи: књижевност за децу, академске студије националне књижевности, наставичке академске студије.

Изразито разуђени корпус дела одређен рецепцијским својствима младих читалаца, који обухвата широки узрасни период од најмлађег, прешколског доба до омладинског узраста, књижевност за децу (и младе) у Србији преживела је значајне промене у свом двоиповековном развоју (на овим просторима се развија од половине од 18. века - в. Опачић 2018). Саме представе о детињству, насупрот неким претпоставкама, нису монолитне 2 ,

1 Рад је настао у оквиру пројекта Смена поетичких парадигми у српској книжевности 20. века: национални и европски контекст, бр. 178016, који финансира МПНТР РС.

2 На то указује и Карин Лесник Оберстајн: „претпоставка књижевности за децу о генеричкој универзалности детета заједничка (је) критичком приступу књижевности за децу широм света. Проучавање књижевности за децу у различитим културама јединствено је по приказивању детета као постојећег ентитета, иако се тај постојећи ентитет различито доживљава у оквиру различитих култура - и у оквиру једне исте културе” (Лесник Оберстајн 2013: 34). 
већ су се, условљене вишеструким друштвено-историјским чиниоцима, мењале кроз епохе, што је утицало не само на обликовање књижевних текстова, већ и на омеђивање корпуса (у који спадају и дела заснована на тематизацији детињства и младости, као и дела која су временом, постепено урастала у корпус).

Изучавање овог поља књижевности на овим просторима започиње почетком 20. века првим књигама и антологијама: прва књига посвећена овој области је књига Милана Шевића Дечја књижевност српска из 1911. а нешто касније, 1936. године излази и Антологија југословенске савремене дечје књижевности Живојина Карића. ${ }^{3}$ Упоредо с тим одвија се постепена афирмација поезије за децу Јована Јовановића Змаја (која је умногоме амблематична за национални корпус), која започиње Скерлићевим (1914), па затим и Богдановићевим ставовима (1929). ${ }^{4}$ Нагли развој проучавања везан је за период после Другог светског рата и делатност Симе Цуцића (Из дечје књижевности, 1951) и Милована Данојлића (почев од чланака „Медведи и зечеви нису криви” из 1958, „Дечје у човеку и детету. Прави лик дечје песме” из 1960, „Ка стварном разумевању дечје песме” 1963, до поступне изградње теорије наивне песме у књигама Лирске расправе из 1967, Овде поток, онде цветиз 1973, Наивна песма: огледи о дечјој књижевности из 1976), али и појединачних текстова Бранка Миљковића („Поезија за децу и осетљиве”, 1955), Душана Радовића („Дете и књига”, 1959), Данила Киша („Дечје - као маска”, 1960) и Григора Витеза („Дјетињство и поезија”) ${ }^{5}$ којима се мењало разумевање и одређење овог поља књижевности. У

3 Почетке 20. века карактерише и негативан став о књижевности за децу Богдана Поповића, који је не сматра књижевношћу у пуном смислу (Поповић 1904). Међутим, ситуација се брзо променила: већ после рата надреалистичка представа о детињству и књижевности за децу радикално је другачија од модернистичке. Три деценије после Поповића, Марко Ристић изједначава биће поезије и наивну дечју природу: „Начело поезије и начело детињства је у суштини исто” (Ристић 1934: 370).

4 Скерлић у њој проналази „не суво педагошки” дискурс и сматра је најбољом поезијом у којој су „велике истине људске и благородна човечанска осећања казивана приступачно, лепо и просто” (Скерлић 1921: 304-305). Милан Богдановић сматра како је у певању за децу Змај најбољи лиричар (Богдановић 1929: 588).

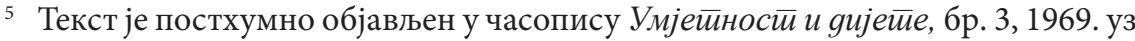
напомену да је настао 1960. 
60-им годинама објављене су четири антологије поезије за децу у којима је видљиво различито одређење корпуса и у којима су примењени разноврсни антологичарско-критички приступи: Врт детињства - антологија дечје поезије српске и хрватске (од Змаја до данас) Борислава Павића (1960), Антологија савремене поезије за деиу Воје Царића (1961), Дечја поезија српска Боре Ћосића (1965) и Антологија југословенске поезије за децу Живојина Карића (1966) - ове антологије, међу којима је свакако најзначајнија она Ћосићева, доприносе постепеном стабилизовању књижевног поља.

Монографије посвећене изучавању књижевности за децу у шездесетим и седамдесетим годинама, које објављују Владимир Миларић (Време као играчка, 1967; Интерпретација дечје песме, 1975), Воја Марјановић (Детињство и поезија, 1968; Огледи из савремене књижевности за децу, књ. 1. (српски песници за децу), 1971), Слободан Ж. Марковић (Записи о књижевности за децу, 1971), Милан Пражић (Игра као слобода: записи о детињству и уметности, 1971) и Драгутин Огњановић (Ствараоци и деца, 1978) показују како је она постала саставни део српске науке о књижевности. Године 1975. оснива се и први часопис посвећен проучавању ове области, часопис Детињство Међународног центра за књижевност за децу Змајеве дечје игре у Новом Саду. Његов први уредник био је Владимир Миларић (1975-1984) а председник Управног одбора био је Слободан Ж. Марковић, који од 1984. до 1993. обавља и посао главног и одговорног уредника. Књижевност за децу постаје академска дисциплина и у другим републикама тадашње заједничке државе, па треба издвојити важан научни рад Милана Црнковића (1925-1998) у Хрватској, Нова Вуковића (1937-2002) у Црној Гори, Муриса Идризовића (1925-2009) у БиХ и Миодрага Друговца (1928-1995) у Македонији који су монографијама и академским наставним активностима развијали проучавање ове дисциплине.

Као академска дисциплина у Србији књижевност за децу почиње да се проучава прво на Филолошком факултету у Београду, пре свега захваљујући залагању проф. др Слободана Ж. Марковића (1928-2015) који уводи овај студијски предмет на тада- 
шњој Катедри за југословенске књижевности. Марковић је књижевност за децу држао од 1956. као семинар, а стални предмет уводи када је постао доцент 1964. Његови биографи истичу да је то био први семинар књижевности за децу у овом делу Европе (в. Јерков, Сувајџић 2018). Већ од 1957. почиње да пише прве радове из ове области у којима су видни књижевноисторијски импулси (фасцинантно је да су први радови, иако настали у младим годинама, представљали периодизацијске скице међуратне, ратне и послератне књижевности). ${ }^{6}$ Такође, његова књига Записи о књижевности за децу и касније монографије (Марковић 1982; 2003; $2007)$ користила се и као уџбеник на факултетима (неке од поменутих књига Миларића, Марјановића, Пражића, Огњановића и др. такође су произашле су из наставе на педагошким академијама на којима су се школовали будући учитељи и васпитачи а почев од деведесетих јављају се и прве опсежније периодизације, обликоване као историје књижевности за децу: Јекнић 1994; 1998; Петровић 2001; Милинковић 2010). Осим тога, Марковићева Антологија српских прича за дещу објављена је у Српској књижевној задрузи исте 1984. године кад и Антологија српске поезије за децу Душана Радовића, па ове две здружене антологије, заједно са Марковићевом каснијом Антологијом српских поема за децу (1996) представљају значајан поетички пресек модерне књижевности за децу у њеним главним видовима, поезији, краћој прози и лирско-епским врстама. ${ }^{7}$

6 „Проза за децу Иване Брлић-Мажуранић”, Кюижевност и језик, год. 6, бр. 7-8 (1957), 278-283; „Књижевност за децу настала између два светска рата на српскохрватском језичном подручју", Кғижевност за деиу и рад у дечјим библиотекама: зборник материјала са семинара за рад у дечјим библиотекама, Београд, Савет друштва за старање о деци и омладини Југославије, 1958, 67-70; „Књижевност за децу у току и после Другог светског рата", Кюижевност за деиу и рад у дечјим библиотекама, Београд: Савет друштава за старање о деци и омладини Југославије: Комисија за литературу и штампу за децу, 1958, 70-113; „Македонска књижевност за децу (1945-1955)", Кюижевност за деиу и рад у дечјим библиотекама, Београд: Савет друштава за старање о деци и омладини Југославије: Комисија за литературу и штампу за децу, 1958, 138-161.

7 Антологија српских поема за дещу и даље представља једину антологију и систематично истраживање овог жанра. 
У време Слободана Ж. Марковића наставу је држали су и проф. др Живан Живковић (1952-1996) и Христо Георгијевски (1943-2000). Живковић је, такође, био уредник Детињства од 1993. до своје преране смрти; затим аутор књиге Са странища Детињства, коју су издале Змајеве дечје игре 1998. а припада му и заслуга проширивања корпуса српске књижевности за децу у 18. век (у тексту „О почецима српске поезије за децу” из 1987. он први показује да се неки текстови из Калиграфије Захарија Орфелина могу сматрати почецима ове области). Осим њега, и Христо Георгијевски значајан је по монографији Роман у српској књижевности за децу и младе (2005).

\section{Књижевност за децу као}

\section{академска дисциплина у региону}

Књижевност за децу као студијски предмет у региону везује се за студије националног језика и књижевности (што указује на доминацију националног корпуса у проучавању ове области) и за наставничке студије на учитељским или педагошким факултетима (за студенте који се школују за васпитаче и за учитељски позив). Овај студијски предмет јавља се у различитим терминолошким варијацијама и заузима различит статус (обавезни/ изборни) по обиму предмета, тј. броју ЕСПБ и по броју недељних часова. Најчешће се изучава на основним академским студијама, а у неким случајевима и на мастер студијама. У том смислу запажа се различит статус који ова дисциплина заузима у односу на врсту студијског програма. На студијама националне књижевности и језика на универзитетима у региону овај предмет некад изостаје (на компаратистичким студијама га по правилу ни нема, и поред компаратистичког аспекта ове дисциплине), чешће се јавља као изборни предмет и свеукупно има много мањи фонд часова у односу на превасходно наставнички орјентисане факултете. Гледано у односу на укупни курикуларни концепт наставних области а судећи и по броју часова у оквиру којих се изводи настава, па и по обиму лектире и литературе - овај академски предмет најчешће не спада у доминантне предмете, чак ни на наставничким факултетима, и поред чињенице да ће дипломирани студенти не- 
посредно користити своја знања из ове области (у раду са предшколском децом или ученицима млађег узраста). Томе сведоче подаци из неколико република у окружењу ${ }^{8}$

У Хрватској овај студијски предмет изучава се на филозофским и наставничким факултетима у Загребу, у Ријеци и Осијеку. ${ }^{9}$ Јавља се у терминолошким варијацијама: као (Хрватска) Дјечја књижевност, Књижевност за дјецу и младеж и Дјечја књижевност са медијском културом, чак и као Дјечја књижевност на енглеском језику. У највећем броју случајева реч је о једносеместралном обавезном предмету који носи различит број ЕСПБ и фонд часова. Једини изузетак је Учитељски факултет Универзитета у Загребу (уз наставна одељења Учитељског факултета у Чаковцу и Петрињи), где се заправо протеже на целу годину кроз једносеместралне предметеи подељен је на национални корпус (Хрватска дјечја књижевност, 4 ЕСПБ, 1+2) и корпус опште књижевности (Свјетска дјечја књижевност, 3 ЕСПБ, 1+1). На филозофским факултетима у свим универзитетским центримавезан је за студије кроатистике: у Загребу је Хрватска дјечја књижевност изборни предмет (5 ЕСПБ) на преддипломском једнопредметном студију (5. семестар), на Филозофском факултету у Ријеци Књижевност за дјецу и младеж је обавезни предмет на првом семестру (3 ЕСПБ, 2+1) а на Свеучилишту Јосипа Јурја Штросмајера у Осијеку обавезни је предмет у 6. семестру (5 ЕСПБ, 2+2). Сва три универзитета имају и наставничке факултете на којима се књижевност за децу изучава у оквиру интегрисаног учитељског студијског програма и програма Рани и предшколски одгој и образовање.У Ријеци предмет намењен образовању учитеља носи 4 ЕСПБ (2+1) у 5. семестру, а за образовање васпитача Дјечја књижевност са медијском културом изучава се у 3. семестру (4 ЕСПБ, 2+1); у Осијеку се на Факултету за образовне и одгојне знаности изучава на интегрисаном преддипломском и дипломском учитељском студију у оквиру модула за развојни смер, за информатику (у оба случаја предмет у 2. семестру има 3 ЕСПБ, 1+1) и

${ }^{8}$ Подаци су прикупљени на основу јавно доступних података о студијским програмима на факултета и универзитета.

${ }^{9}$ И наставна одељења ових факултета у другим градовима. 
за енглески (Дјечја књижевност на енглеском језику, са лектиром прилагођеном енглеском говорном подручју и са истим обимом).

У Словенији се изучава на универзитетима у Љубљани, Марибору и Копру. У Љубљани се Младинска књижевност изучава као једносеместрални предмет само на Педагошком факултету, на другој години основних студија за учитеље (3. семестар, 5 ЕСПБ, $1+2)$; постоје и изборни предмети od 4 ЕСПБ (2+2): Интеркултурна књижевност за децу (Medkulturna mladinska književnost) и Сликовница (Slikanica), па је тиме ипак у извесном смислу заступљена током два семестра. На Филозофском факултету курикулум не предвижа овај предмет. У Марибору је боља ситуација: Младинска књижевност изучава се на Педагошком факултету на студијским програмима за учитеље и за васпитаче у предшколском узрасту (Predšolska vzgoja) у зимском семестру треће године и простире се на обим од 4 ЕСПБ, али само два часа наставе $(2+0$, односно самостални рад).Студије словеначког језика и књижевности на Филозофском факултету садрже и једносеместралну Младинску књижевност која на једнопредметном студијском програму носи 4 ЕСПБ (2+1) а на двопредметном студијском програму носи 3 ЕСПБ (2+0). У Копру се ова дисциплина јавља на мастер студијама словенистике, у оквиру педагошког студијског програма, као изборни предмет из области наставе књижевности (Младинска књижевност, 6 ЕСПБ). ${ }^{10}$

У Босни и Херцеговини Књижевност за дјецу, односно Књижевност за дјецу и омладину изучава се на Филозофском факултету Универзитета у Сарајеву на одсеку за Књижевности народа БиХ (наставнички смер) током целе академске године, а градиво је подељено не по националном корпусу, као у Хрватској, већ жанровски, на два самостална једносеместрална испита: Књижевност за дјецу и омладину - бајка, басна, поезија и граничне вр$\mathrm{cme}^{11}$ (4 ЕСПБ, 2+2) и Књижевност за дјецу и омладину - приповједна проза и роман (4 ЕСПБ; 2+2), као и на мастер студијама одсека за босански, хрватски и српски језик и књижевности народа БиХ (наставнички смер) као Поетички феномени књижевности

${ }^{10}$ Нису доступни подаци о броју часова.

${ }^{11}$ Није јасно по ком начелу су распоређени жанрови у називу предмета. 
за дјаеиу и омладину (4 ЕСПБ, 2+2). Осим тога, изучава се и на Педагошком факултету Универзитета у Бихаћу, у оквиру студијских програма Предшколски одгој (Књижевност за дјеuу, 5 ЕСПБ, 3+1) и Разредна настава (Књижевност за дјецу, 4 ЕСПБ, 3+1) у другој години студија.

У Републици Српској књижевност за децу је заступљена и на студијским програмима србистике и на наставничким факултетима или студијским програмима, у Бања Луци, Бијељини и на Палама. Највећи фонд предмет има на Педагошком факултету у Бијељини Универзитета у Источном Сарајеву. Ту је Књижевност за дјецу обавезни једносеместрални предмет на студијском програму Разредне наставе од чак 7 ЕСПБ $(3+3)$ који се одржава у 4. семестру. И студијски програм Предшколско васпитање и образовање има обавезан једносеместрални предмет, али са мањим обимом (6 ЕСПБ, 2+2). Осим тога изучава се и на Катедри за србистику Филозофског факултета Пале (под називом Дјечија књижевност), као обавезан једносеместрални предмет од 4 ЕСПБ (2+1) у петом семестру основних студија. И на учитељском студију Филозофског факултета у Бања Луци јавља се као обавезан предмет на другој години основних студија у два облика: као Књижевност за дјецу (6 ЕСПБ; 2+2) и као Књижевност за предшколску дјецу (4 ЕСПБ; 3+1) на студијском програму Предшколско васпитање.

На Универзитету Црне Горе овај студијски предмет не изучава се на Филолошком факултету (где напоредно постоје студијски програми српског језика и књижевности и црногорског језика и књижевности), већ на студијским програмима за образовање учитеља и предшколско васпитањекоји се изводе на Филозофском факултету. Именован као Књижевност за дјецу и омладину, једносеместрални обавезни предмет изучава се у 4. семестру основних академских студија, али са већим бројем часова (5 ЕСПБ, 3+2).

У Македонији студије македонског језика и књижевности на Универзитету у Скопљу не садрже изучавање ове дисциплине, али се овај предмет изучава на Филолошком факултету у Штипу као једносеместрални на другој години основних студија македонског језика и књижевности под називом Книжевност за деца 
и са значајним фондом часова (6 ЕСПБ, $2+2+1)$. Осим тога, Книжевност за деца и млади као академска дисциплина изучава се као једносеместрални изборни предмет на Педагошком факултету у Битољу, на студијским програмима везаним за наставнички позив: за учитеље (Наставник во оддленска настава), за васпитаче (Воспитувач), а за наставнике македонског језика и књижевности као Литература за деца и млади.

\section{Академско проучавање књижевности за децу у Србији}

Ова универзитетска средина иницирала је академско проучавање књижевности за децу. Од увођења на академске студије, област се проучавала као студијски предмет на филолошким/ филозофским факултетима у оквиру студија националне књижевности и језика а уз то и на вишим школама за образовање наставника и васпитача. ${ }^{12}$ У оквиру свих универзитета данас постоји шест учитељских/ педагошких факултета (у Београду, Сомбору, Ужицу, Јагодини, Врању и Лепосавићу) (и, такође, у Суботици, где се студије изводе на мађарском језику). Осим тога, настава из овог предмета држи се и на бројним институцијама струковних студија (Нови Сад, Кикинда, Сремска Митровица, Шабац, Крушевац, Алексинац, Пирот) којима се нећемо бавити у овом раду.

Предмет се изучава на универзитетским студијама у оквиру готово свих студијских програма српске књижевности и језика (србистике) (универзитетски центри у Београду, Новом Саду, Крагујевцу, Нишу, Новом Пазару) и у оквиру студијских програма за образовање учитеља и васпитача на учитељским/ педагошким факултетима (у Београду, Сомбору, Јагодини, Ужицу, Врању, Лепосавићу).

На студијама српске књижевностипредмет под називом Књижевност за децу обавезан је једносеместрални предмет са

12 Првобитне Педагошке академије, касније учитељске школе, раслојиле су се 1993. на учитељске факултете који су постали део универзитета и двогодишње више школе за образовање васпитача, које су се даље трансформисале у трогодишње, високе школе струковних студија, у новије доба са основним и мастер нивоом струковних студија. Неке од високих школа струковних студија за образовање васпитача су недавно обједињене у Академију васпитачко-медицинских струковних студија са седиштем у Крушевцу, односно у Академију струковних студија Западна Србија са седиштем у Ужицу. 
лектиром која подразумева доминантни национални канон и репрезентативни избор дела светске књижевности и са различитим фондом часова који нужно не корелира са бројем ЕСПБ. На Филолошком факултету у Београду изучава се на два сродна студијска програма: Српској књижевности и језику и Српској књижевности и језику са компаратистиком на четвртој години студија (6 ЕСПБ, 2+1). На Филозофском факултету у Новом Саду постоји на студијском програму Српска књижевност и језик и јавља се у два облика, као Књижевност за децу у настави (3 ЕСПБ) са малим бројем часова $(1+1)$ у четвртом семестру и као Англоамеричка дечија књижевност, изборни предмет условљен нивоом знања енглеског језика (услов енглески Б.2) у истом обиму (3 ЕСПБ). На србистици Филолошко-уметничког факултета Универзитета у Крагујевцу изучава се у трећој години основних студија (4 ЕСПБ, 2+2), на Филозофском факултету у Нишу са мањом обимом и фондом часова (3 ЕСПБ, $1+1)$ на другој години студија а на Српској књижевности и језику ${ }^{13}$ Државног универзитета у Новом Пазару изучава се једносеместрална Књижевност за децу и омладину (5 ЕСПБ, 2+2). Међутим, ове академске дисциплине насродној студијској групи Филозофског факултета Универзитета у Приштини са привременим седиштем у Косовској Митровици уопште нема. Статус овог предмета наглашенији је на учитељским/педагошким факултетима, што је, донекле, логично, с обзиром на нижи узраст којим ће се бавити дипломирани студенти, али се и ту разликује по броју часова, оптерећењу и распрострањености у курикулуму универзитетских институција. У оквиру студијских програма за образовање учитеља и васпитача јавља се увек као обавезни предмет, ређе једносеместрални а чешће као двосеместрални, уз опционо постојање изборних курсева из ове области, најчешће на основним студијама (ређе на мастер студијама). Као двосеместрални предмет постоји у академским институцијама у Београду, Ужицу, Јагодини и Врању а као једносеместрални предмет у Сомбору, на програму за васпитаче у Врању и у Приш-

\footnotetext{
13 У опису студијског програма указује се да се историја српске књижевности изучава „с посебним акцентом на бошњачку књижевност” - http://www.dunp.np.ac.rs/ srpska-knjizevnost-i-jezik/
} 
тини са привременим седиштем у Косовској Митровици (факултет је ситуиран у Лепосавићу). На Учитељском факултету у Београду изучава се на основним студијама као двосеместрални предмет Књижевност за децу и младе на трећој години студија (6 ЕСПБ, 2+2, 2+2), уз неколико изборних једносеместралних курсева на основним студијама (Појам и одређење ауторске бајке на 3. години, 3 ЕСПБ за учитеље / 4 ЕСПБ за васпитаче; Књижевно стваралаштво за децу и младе на румунском језику у Републици Србији (3 ЕСПБ) (у наставном одељењу у Вршцу); Млади јунаку савременом српском романуза децу - методички аспект на четвртој години, 3 ЕСПБ, као део изборног курса Развијање језичких знања и вештина на енглеском језику у оквиру модула за енглески језик на другој години - 3 ЕСПБ) и као изборни једносеместрални предмет на мастер студијама (Савремени приступи књижевности за децу, 5 ЕСПБ, 2+1). На Педагошком факултету у Ужицу за учитеље држи се као обавезни двосеместрални предмет на трећој години студија (4 ЕСПБ, 2+1, 2+1) а за васпитаче на другој години студија (5ЕСПБ, 2+1, 2+1). На Факултету педагошких наука у Јагодини ово је обавезни двосеместрални предмет за учитеље и васпитаче у предшколским установама на другој години студија (5 ЕСПБ, 2+1, $2+1)$. На Педагошком факултету у Врању за учитеље Књижевност за децуноси 6 ЕСПБ (2+2), уз изборне Драматизација књижевног текста за децу (3 ЕСПБ, 2+0) и Лектира у разредној настави у истом обиму а за васпитаче је једносеместрални предмет на другој години студија (6 ЕСПБ, 4+2). На Учитељском факултетуса привременим седиштем у Лепосавићу будући учитељи на трећој години изучавају једносеместрални предмет са повећаним бројем часова (5 ЕСПБ, 4+2) а васпитачи у предшколским установама на првој години основних студија са истим обимом и бројем часова.

На Педагошком факултету у Сомбору Књижевност за децу је једносеместрални предмет за учитеље и за васпитаче на трећој години студија и одржава се са сразмерно малим укупним бројем часова (3 ЕСПБ, 2+1). Уз овај предмет настави ове дисциплине припадају и изборни предмети, чиме се у извесном смислу надомешћује заступљеност на обавезном делу студија, уз то са већим фондом часова: Увод у позоришну уметност (6 ЕСПБ, 2+2) за 
учитеље и Поетика књижевности за деиу за васпитаче са истим обимом. Помало невероватна је чињеница да унутар истог курикулума настава на енглеском језику из ове области има двоструко већу заступљеност у курикулуму. Она обухвата два предмета: Увод у дечју књижевност на енглеском језику (6 ЕСПБ, 2+2) иАнглоамеричка књижевност за деиу (6 ЕСПБ, 2+2).

Наведени подаци указују дакао студијски предмет, Књижевност за децу (и младе) која је и поникла из академског изучавања српске књижевности и уз њу се понајвише везује својим садржајем, на матичним студијама има нешто нижи значај (мањи фонд часова, број ЕСПБ и траје један семестар - или уопште не постоји у студијском програму) у односу на друге предмете (укупни статус у оквиру курикулума студијских програма) и у односу на наставничке факултете. Чињеница је и да се ова дисциплина проучава и на компаратистичким студијама једино на Филолошком факултету у Београду.

\section{Концепт силабуса на Учитељском факултету у Београду}

Од оснивања факултета књижевност за децу, као што смо већ навели, постаје обавезни предмет у курикулумима студијских програма за образовање учитеља, а затим и васпитача (од 2007). Први професор овог предмета био је Драгутин Огњановић (1933-1999). Предмет је конципиранкао поетичко и књижевноисторијско кретање кроз родове и жанрове усмене и уметничке, националне и светске књижевности, односно кроз испитивање еволуције жанрова у компаративном контексту. У уводном делу курса указује се на статус, поетику, корпус и периодизацију овог поља књижевности, на његову вишеструку и вишезначну повезаност са књижевношћу за одрасле и на измене њеног статуса и одређења у односу на конструкте детињства у разним епохама. Други део курса подразумева испитивање поетичког развоја у оквиру појединачних жанрова и на примерима прописане лектире из националне и светске књижевности: поезија (кроз три развојне етапе), лирско-епске врсте (у народној и уметничкој књижевности), народна књижевност, проза (басна, бајка, прича) а трећу област чини изучавање врста романа, драмске књижевности, не- 
фикционалних жанрова (путописи, дневничка проза, мемоари и аутобиографије и популарна наука), савремене књижевности и проучавања књижевности за децу у историјском развоју - све то на одабраној лектири. Историјска поетика жанрова подразумева широку вертикалу, па прописана лектира обухвата распон од почетака књижевности за децу (нпр. басна у античко доба, бајка у класицизму, српска поезија у 18. и 19. веку) до савремене књижевности у најужем смислу (дела и аутори из 21. века), при чему је избор из националног корпуса је доминантан у односу на избор из светске књижевности. Иако је настава на основним студијама заснована на примени различитих методолошких приступа у проучавању овог поља књижевности, теоријском приступу се посвећује посебна пажња на мастер студијама, при чему се студенти који одаберу овај курс осамостаљују да изводе тумачење применом одабраних научних метода. Чињеница је да ова академска дисциплина на значајан начин заступљена у оквиру курикуларног концепта академских студија на основним и мастер студијама (ако узмемо у обзир и изборне предмете, она се простире на две године основних студија и на мастер студије и обухвата 6+3+3+3 ЕСПБ на трећој години, 3 ЕСПБ на четвртој и 5 ЕСПБ на мастеру). ${ }^{14}$

Треба на крају напоменути да, укупно гледано, у националном и регионалном контексту, силабуси књижевности за децу не садрже у довољној мери репрезентативни избор дела из породице словенских књижевности (нпр. у силабусу на Учитељском факултету у Београду су од словенских књижевности заступљени аутори словеначке, хрватске и руске књижевности, што није довољно). Због тог је нужно успоставити заједничку славистичку платформу и укључити што шири корпус аутора словенских књижевности у опште академско изучавање ове области. Студенти филолошких и учитељских/ педагошких факултета професионално су везани за наставу и рад са млађим нараштајима, чиме се дугорочно утиче на генерације широке читалачке публике и, самим тим, на познавање књижевности и култура словенских народа, чиме се снажи свест о међусобној сродности.

\footnotetext{
${ }_{14}$ Изборни предмет на Модулу за енглески језик на другој години студија подразумева изучавање књижевности за децу на енглеском језику, али и развијање језичких и методичких компетенција.
} 


\section{ЦИТИРАНА ЛИТЕРАТУРА}

Богдановић 1929 - Богдановић, Милан, „Дечја поезија Змајева”, Београд: СКГ, књ. 26, 8, 588-594.

Витез 2011 - Витез, Григор, „Дјетињство и поезија”, у: Григор Витез, Очи траже свјетлост, Изабрана дјела, прир. Никола Вујчић, Загреб: СКД Просвјета, 67-117.

Вуковић 1996 - Вуковић, Ново, Увод у дјечју књижевност, Подгорица: Унирекс.

Георгијевски 2005 - Георгијевски, Христо, Роман у српској књижевности за децу и младе, Нови Сад: Змајеве дечје игре.

Данојлић 1967 - Данојлић, Милован, Лирске расправе. Нови Сад: Матица српска.

Данојлић 1973 - Данојлић, Милован, Онде поток, онде цвет, есеји и записи о дечјој књижевности, Нови Сад: Змајеве дечје игре, Раднички универзитет „Радивој Ћирпанов“.

Живковић 1987 - Живковић, Живан, „О почецима српске поезије за децу", Детињство, Нови Сад, год. ХІІІ, бр. 1 -2, пролеће-лето 1987, 41-47.

Живковић 1998 - Живковић, Живан, Са страница Детињства, Нови Сад: Змајеве дечје игре. MAK.

Јекнић 1994 - Јекнић, Драгољуб, Српска књижевност за деиу, Београд:

Јекнић 1998 - Јекнић, Драгољуб, Српска књижевност за децу 1: историјски преглед, Београд: МАК.

Карић 1936 - Карић, Живојин, Антологија југословенске савремене дечје књижевности, књ. 1, Поезија, Београд: Издавачка књижара Јеремије Ј. Џелебџића.

Карић 1966 - Карић, Живојин, Антологија југословенске поезије за децу, Титоград: Графички завод.

Киш 1995 - Kiš, Danilo, „Дечје - као маска: нова књига стихова Милована Данојлића" - НИН, X: 487 (8. мај 1960), 9 - коришћено издање: Вариа, Сабрана дела Данила Киша, књ. 12, прир. М. Миочиновић, Београд: БИГЗ, 1995.

Киш 1995 - Kiš, Danilo, „Дечје - као маска: нова књига стихова Милована Данојлића" - НИН, X: 487 (8. мај 1960), 9.

Лесник Оберстајн 2013 - Лесник Оберстајн, Карин, „Основи: шта је књижевност за децу? Шта је детињство", у Питер Хант (ур.). Тумачење књижевности за децу, превела Н. Јанковић, приредила 3. Опачић, Београд: Учитељски факултет.

Љуштановић 2012 - Љуштановић, Јован, Књижевност за деиу у огледалу културе, Нови Сад: Змајеве дечје игре. Багдала.

Марјановић 1968 - Марјановић, Воја, Детињство и поезија, Крушевац: 
Марјановић 1971 - Marjanović, Voja,Ogledi iz savremene književnosti za decu, Knj. 1 (srpski pesnici za decu),Beograd: Obelisk.

Марјановић 2000 - Марјановић, Воја, Књижевност за децу и младе. Део 1, Поетика, писци, дела, Београд: Виша школа за образовање васпитача.

Марковић 1971 - Марковић, Слободан Ж., Записи о књижевности за деиу, Београд: Интерпрес.

Марковић 1982 - Марковић, Слободан Ж., Записи о појавама у књижевности за децу, Горњи Милановац: Дечје новине.

Марковић 1984 - Марковић, Слободан Ж., Антологија српске приче за деиу, Београд: СКЗ.

Марковић 1996 - Марковић, Слободан Ж., Антологија српских поема за деиу, Београд: СКЗ.

Марковић 2003 - Марковић, Слободан Ж., Записи о књижевности за деиу III: појаве, жанрови, рецепција, Београд: Београдска књига, 2003.

Марковић 2007 - Марковић, Слободан Ж., Записи о књижевности за деиу IV: писци и дела, Београд: Београдска књига.

Милинковић 2010 - Милинковић, Миомир, Нацрт за периодизацију српске књижевности за децу, Нови Сад: Змајеве дечје игре.

Миљковић 1955 - Миљковић, Бранко, „Поезија за децу и осетљиве”, Вuдищи, III, 15-16, 9.

Огњановић 1978 - Ognjanović, Dragutin, Stvaraoci i deca: ogledi i studije iz jugoslovenske književnosti,Beograd: Nova knjiga.

Огњановић 1997 - Огњановић, Драгутин, Дечје доба: студије и огледи из књижевности за дещу, Београд: Пријатељи деце Београда.

Опачић 2018 - Опачић, Зорана, „Два и по века српске књижевности за децу и младе", У Антологија књижевности за децу 1, Нови Сад: Издавачки центар Матице српске, 14-49.

Опачић 2019 - Опачић, Зорана, (Пре)обликовање читаоца, Београд: Учитељски факултет.

Павић 1960 - Павић, Борислав, Врт детињства - Антологија дечје поезије српске и хрватске (од Змаја до данас), Сарајево: Свјетлост.

Петровић 2001 - Петровић, Тихомир, Историја српске књижевности за децу, Врање: Учитељски факултет.

Поповић 1904 - Поповић, Богдан, „Јован Јовановић Змај”, СКГ, Београд, књ. XII, бр. 4-5, 16. VI 1904, 929-938; 1.VII 1904,1000-1014; Огледи из књижевности и уметности, Београд: С. Б. Цвијановић, 157-189.

Радовић 1984 - Радовић, Душан, Антологија српске поезије за дещу, Београд: СКЗ.

Радовић 2009 - Радовић, Душан, „Дете и књига”, у: Љуштановић, Јован. Принцеза лута замком, Теоријска мисао о књижевности за деиу из окриља Змајевих дечјих игара, Нови Сад: Змајеве дечје игре, 19-22.

Ристић 1934 - Ристић, Марко, „О модерној дечјој поезији. Поводом књиге Подвизи дружине Пет петлића", Данас,I / 3, 366-372. 
Скерлић 1921 - Скерлић, Јован, Историја нове српске књижевности, друго издање, Београд: Издавачка књижарница Геце Кона (прво издање 1914)

Ћосић 1965 - Ћосић, Бора, Дечја поезија српска, Нови Сад: Матица српска; Београд: СКЗ. Цуцић 1951 - Цуцић, Сима, Из дечје књижевности: осврти и чланци, Нови Сад: Матица српска.

Шевић 1911 - Шевић, Милан, Дечја књижевност српска: оглед историјског прегледа, Нови Сад: „Натошевић”.

\section{ДЕТСКАЯ И МОЛОДЕЖНАЯ ЛИТЕРАТУРА КАК АКАДЕМИЧЕСКИЕ ДИСЦИПЛИНЫ}

В докладе рассматривается развитие изучения детской литературы как академической дисциплины. Впервые в юго-восточной части Европы данная академическая дисциплина была введена в университетское образование Слободаном Ж. Марковичем в конце 50-ых годов прошлого века. В работе прослеживается, каким образом развивался научный подход к дисциплинам такого рода, каково их состояние на сегодняшний день в Сербии и странах региона, при этом особое внимание уделено рассмотрению доминирующих способов обучения и концепций существующих учебных программ. Поскольку в данной статье речь идет о дисциплинах, главным образом изучающихся в рамках национальной литературы и в рамках педагогического университетского образования, в учебных программах преобладают произведения национальных писателей с подборкой наиболее представительных произведений европейской и мировой литературы. Анализ учебных университетских программ позволил сделать вывод о необходимости большего присутствия славянских литератур в академических учебных программах.

Ключевые слова: детская литература, университетское изучение национальной литературы, педагогическое образование. 